\title{
THE GENERIC NAMES MYRMECOPHAGA AND DIDELPHIS.
}

\author{
OLIDFIELD THOMAS.
}

THERE have recently appeared in America two papers on these generic names, the one in this journal, by Mr. J. A. G. Rehn, ${ }^{1}$ and the other, criticising the first, by Dr. J. A. Allen. ${ }^{2}$ The points raised in both appear to me to need further discussion, especially with regard to the somewhat ready manner in which the species usually quoted as the type of each name is thrown aside as unrecognizable.

\section{MyrmecophagA.}

With regard to Mymecophaga tridactyla, which, if determinable, would admittedly be the type of the generic name, Mr. Rehn, while discussing Linnæus's references to Seba and Ray, altogether ignores the very first quotation of all, that to Marcgrave ("Tamandua-guacu, Marcgr. bras. 225"). On examination Marcgrave's animal proves to be beyond all question the great ant-eater of Brazil, and on the general principle of taking the first important reference as the basis for Linnæus's names we must clearly accept the great ant-eater as the type of the genus Myrmecophaga.

Linnæus's words, "macula nigra a pectore versus latus ducta" and "cauda lata," are also diagnostic of the great ant-eater, mistaken as are his statements about the digits and mammary formula.

It is unfortunate that the specific name, dating from the tenth instead of the twelfth edition of the Systema Nature, must be tridactyla instead of the familiar jubata; but even this

1 Am. Nat., vol. xxxiv, p. 575, July, r9oo.

2 Bull. Am. Mus. N. H., vol. xiii, p. IS 5 , October, igoo. 
is a lesser evil than the transference of Myrmecophaga to the Tamanduas and the dubbing of the great ant-eater with a new generic name.

Dr. Allen says that while differing about Didelphis, he agrees with Mr. Rehn in regard to Myrmecophaga, but as he seems also not prejudiced (as I am) against dismissing old names as unrecognizable, and has probably not looked up the vital reference to Marcgrave, I do not feel justified in accepting Mr. Rehn's conclusions, even when backed by so great an authority as he is.

As a result I claim that Myrmecophaga tridactyla Linn. should be the name for the great ant-eater, Uroleptes and Cyclopes remaining as before for the other genera of the family.

\section{Didelphis.}

In this case Dr. Allen most rightly refutes the necessity asserted by Mr. Rehn for calling all the large opossums Sarigua instead of Didelphis, but I fail to be convinced as to his application of the specific name marsupialis to the Virginian opossum. This name marsupialis hangs primarily on Seba's figure, and both authors claim that the latter is unrecognizable, Dr. Allen going on to make the remarkable statement that it is "not an American animal, but a species of Phalanger from Amboyna." It is true that Seba said his animal was from Amboyna, but even at that date mistakes could be made as to locality, and no one familiar with Phalanger, its general appearance, dentition, or mammary formula, could for one moment suppose that Seba's figure and description were based on a member of that genus. Among the whole of the Mammalia the peculiar arrangement of the mammæ is alone absolutely diagnostic of a Didelphis, nor have I any doubt what opossum it is meant to represent.

Seba's South American animals nearly all came, as was natural, from Guiana, and the figure will perfectly suit the ordinary dark opossum of northeast South America, for which Dr. Allen has used the name D. karkinophaga. 
This conclusion, if accepted, will have the double advantage of retaining the familiar term virginiana for the Virginian opossum, and abolishing so jaw-breaking a name as karkinophaga.

In the necessity of renaming Philander I am compelled to acquiesce, though I may express a regret that in giving the name Caluromys Dr. Allen has departed from the modern practice of restricting the ending -mys to members of the Rodentia.

But of his transference of the species cinereus and alstoni from Marmosa to Caluromys I find it more difficult to approve, for the points that he mentions as allying them to the latter are all found in different degrees in one or other of the larger species of Marmosa, including $M$. murina, while neither cinerens nor alstoni present those which are more truly characteristic of Caluromys. The general shape of the skull of the latter, the small rounded molars, the great sabre-like canines, the curiously shaped lower jaw, and many other characters make up an cusemble to which, as it appears to me, neither of the species referred to shows any real approximation. I should therefore consider them both as members of the genus Marmosa.

British Museum, Natural mistory. 